\title{
III
}

\section{Dislodgement Resistance of Zirconia Copings Cemented onto Zirconia and Titanium Abutments}

\author{
Umut Güler, DDS, PhD, ${ }^{*}$ Yasemin Budak, DDS, PhD, † José Renato Cavalcanti Queiroz, DDS, PhD, $₫ \S$ \\ and Mutlu Özcan, DDS, Med Dent, PhDף
}

$\mathrm{O}$ sseointegrated implants are a popular option for the restoration of the edentulous areas. In implant therapy, titanium has been the dominant implant and abutment material, and long-term clinical studies on titanium have made the outcomes predictable. ${ }^{1}$ Currently, titanium abutments are considered the gold standard for longevity in implant-borne reconstructions in all regions of the jaw. However, this technology offers many esthetic disadvantages. For example, the use of conventional prefabricated or custom titanium abutments can decrease the translucency of a porcelain restoration, ${ }^{2,3}$ resulting in a darker restoration compared with adjacent natural teeth. In addition, titanium abutments can produce a dark gray metallic hue at the gingival margin of the restoration. This may be most evident in patients with a high smile

${ }^{*}$ Department of Prosthodontics, Faculty of Dentistry, Hacettepe University, Sihhiye Ankara, Turkey (deceased).

fDepartment of Biotechnology, UnP-Laureate University, Natal, Braz

of Prosthodontics, Faculty of Dentistry, State University of Paraiba, Campina Grande, Brazil.

IDental Materials Unit, Clinic for Fixed and Removable Prosthodontics and Dental Materials Science Center for Dental and Oral Medicine, University of Zürich, Zürich, Switzerland.

Reprint requests and correspondence to: José Renato Cavalcanti Queiroz, DDS, PhD, Department of Biotechnology, UnP-Laureate University, Natal, Brazil; and Department of Prosthodontics, Faculty of Dentistry, State University of Paraiba, Campina Grande, Brazil, 59056-000, Phone: +55 843215 1234, E-mail: joserenatocq@hotmail.com

ISSN 1056-6163/17/02604-510

Implant Dentistry

Volume 26 - Number 4

Copyright (C) 2017 Wolters Kluwer Health, Inc. All rights

reserved.

DOI: 10.1097/ID.0000000000000589
Purpose: To determine the effect of the cement type and abutment material on the tensile strength required to dislodge zirconia copings.

Materials and Methods: Two experimental groups of abutments were prepared: (1) titanium abutments $(n=30)$ and (2) zirconia abutments $(n=30)$. Sixty zirconia copings (custom designed) were fabricated using 3-dimensional computer-assisted design to have a 6-mm projection above the abutment to accommodate a hole, through which a wire was inserted to attach the zirconia coping to a universal testing machine. Each abutment was placed onto an implant analog embedded in acrylic resin blocks to fit onto the universal testing machine. The zirconia copings were cemented onto the abutments with a provisional luting agent, zinc

line or with thin gingival tissues. Such poor esthetic outcomes can often make patients unhappy.

To solve this problem, zirconia has been used for abutment manufacturing. ${ }^{4-6}$ The good mechanical properties and biological compatibility of zirconia (zirconium dioxide) have led to its increased use for various dental applications. ${ }^{7,8}$ A number of advantages of ceramics over metal abutments have been reported in the literature: less phosphate (ZP) cement, and adhesive resin cement, and after 5500 thermocycles, a tensile force was applied at a crosshead speed of 0.5 $\mathrm{mm} / \mathrm{min}$. The removal force was recorded for each specimen. Two-way analysis of variance (ANOVA) and 1-way ANOVA were used for the statistical analysis $(\mathrm{P}<0.05)$.

Results: The mean forces necessary to remove the zirconia copings from titanium abutments were 6.52, 83.09 , and $251.18 \mathrm{~N}$ for temporary cement, ZP cement, and resin cement, respectively. For zirconia abutments, the required forces were 17.82, 116.41, and $248.72 \mathrm{~N}$.

Conclusions: The abutment material had no effect on retention, but the cement type affected the retention of the zirconia copings. (Implant Dent 2017;26:510-515)

Key Words: cementation, implant supported, retention 


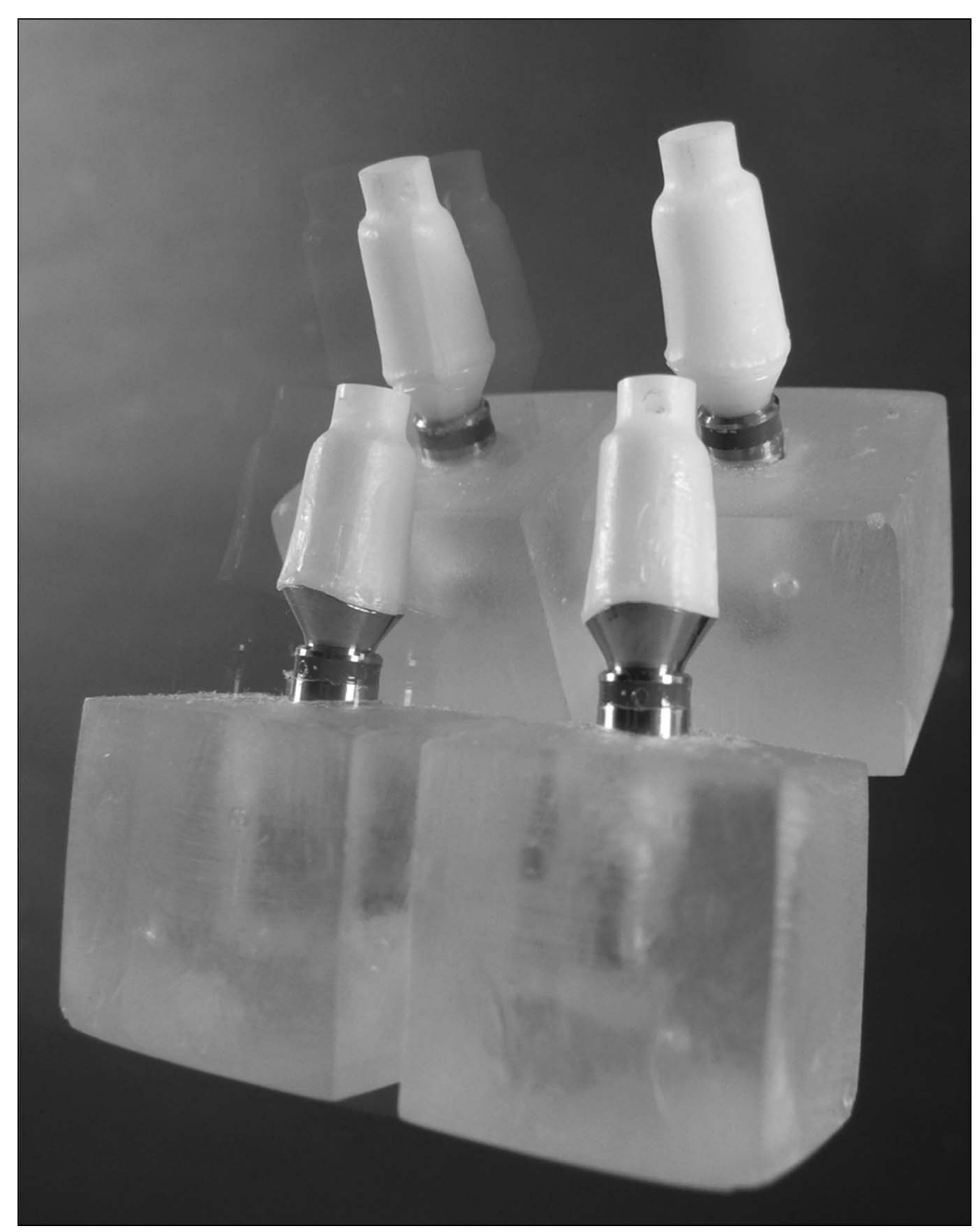

Fig. 1. Representative samples of zirconia copings cemented onto titanium and zirconia abutments, respectively.

Zirconia is a polymorphic material with 4 different crystalline structures. At room temperature, pure zirconia exists in a monoclinic form. The addition of stabilizing oxides to pure zirconia generates a multiphase structure, designated as the metastable tetragonal phase. This phase has good mechanical properties, and stabilized zirconia will display a toughening transformation to this phase under stress. The transformation from the tetragonal to the monoclinic phase is associated with a 3\%-4\% localized volume expansion that induces counteracting compressive stresses in compromised areas. ${ }^{14}$ Besides these favorable mechanical properties, it has also been proposed that zirconia
Table 1. Abutment and Cement Groups

\begin{tabular}{lccc} 
Straumann Ti & ZP Permanent & ZOE Provisional & Resin \\
Implants, $\mathrm{N}=60$ & Cement & Cement & Cement (RC) \\
\hline Ti abutment, $\mathrm{N}=30$ & $\mathrm{n}=10$ & $\mathrm{n}=10$ & $\mathrm{n}=10$ \\
$\mathrm{Zr}$ abutment, $\mathrm{N}=30$ & $\mathrm{n}=10$ & $\mathrm{n}=10$ & $\mathrm{n}=10$ \\
\hline
\end{tabular}

accumulates dental plaque to a lesser extent than titanium. ${ }^{1,15}$

The mechanical and biological properties of zirconia abutments, such as their fracture resistance, peri-implant soft tissue response, plaque accumulation or bacterial attachment onto the abutment, and implant-abutment connection, have all been well studied. Zirconia abutments have a very high fracture resistance that is only slightly lower than that of titanium. Studies have shown that zirconia abutments can function up to 4 years without mechanical problems in the anterior region, and zirconia is as suitable for abutments as titanium in terms of biocompatibility. The biological and mechanical properties of zirconia abutments thus make it as applicable as titanium. ${ }^{1}$ However, zirconia has different mechanical and physical properties than standard titanium implant abutments, and meticulous attention to numerous factors is required to achieve optimal results with zirconia implant abutments. One of the most important factors that can directly affect performance is the abutment design. ${ }^{16}$

Prefabricated zirconia abutments are used either at the time of implant placement or later in the delayed loading protocol. Placing an abutment at the time of implant surgery and never removing it may help reduce the loss of crestal bone due to microgaps. ${ }^{17}$ In a systematic review, the 5-year survival rates of ceramic and metal abutment were estimated as $99.1 \%$ and $97.1 \%$, respectively. The corresponding rates for technical complications were estimated as $6.9 \%$ for ceramic abutments and $15.9 \%$ for metal abutments. The most frequent complication was loosening of the abutment screw, which occurred in $5.1 \%$ of patients. ${ }^{18}$ The strengths of titanium and ceramic abutments have been tested with load-tofracture tests and compared with the maximum occlusal force to determine their survival rates. ${ }^{17,19-22}$ The fracture strength of zirconia abutments $(294 \pm$ $53 \mathrm{~N}$ ) was found to be significantly higher than that of alumina abutments $(239 \pm 83 \mathrm{~N}){ }^{19}$

Various ceramic materials are used to produce restorations with better esthetic properties in the anterior 


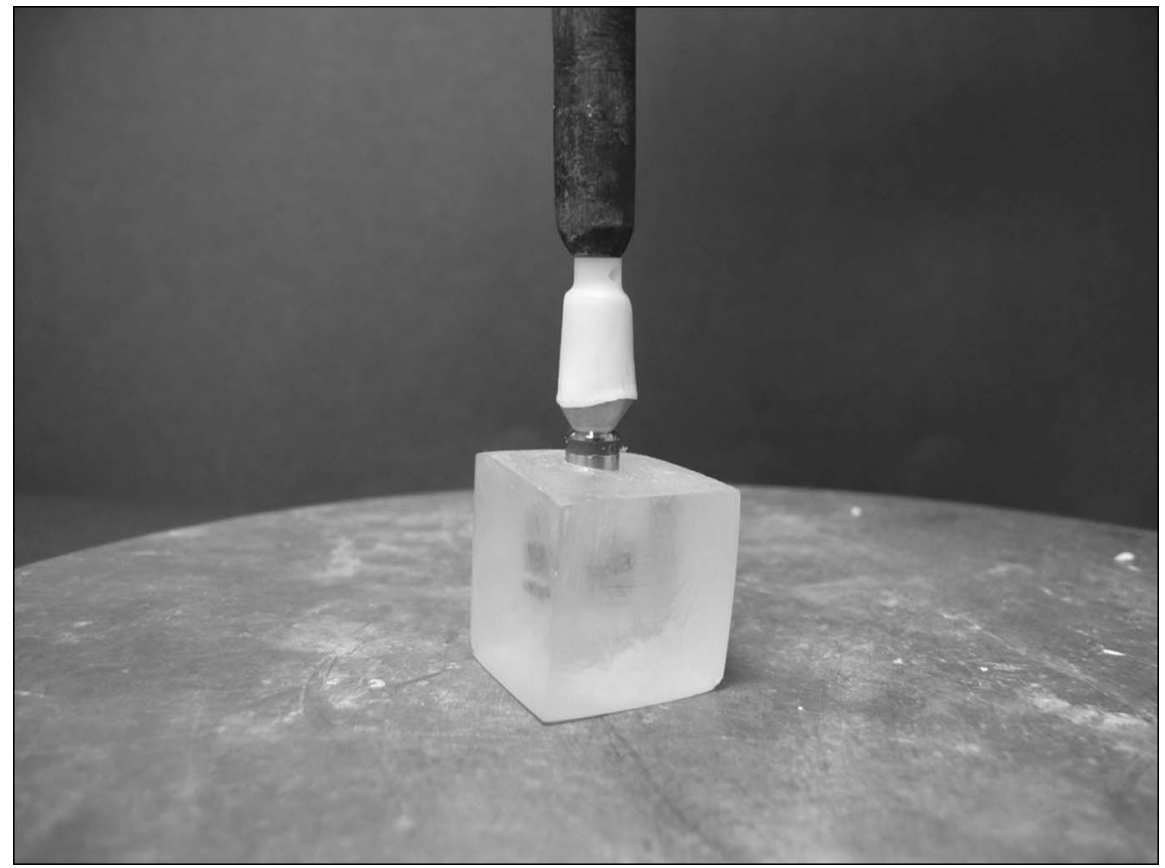

Fig. 2. Representative sample of zirconia coping being seated onto the abutments under compression load (20 N) for 10 minutes.

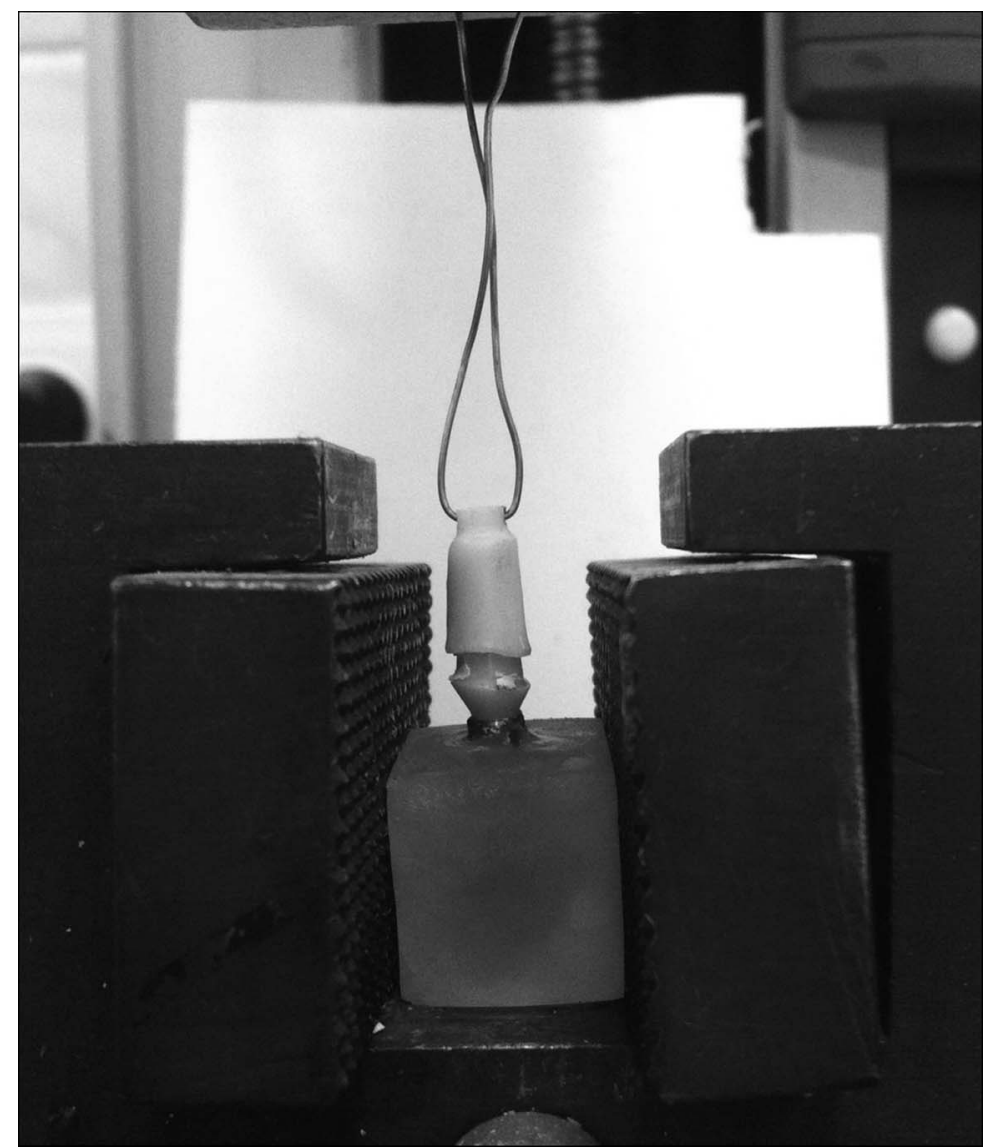

Fig. 3. Representative sample of pull-out test using tensile load in a universal machine (crosshead speed of $0.5 \mathrm{~mm} / \mathrm{min}$ ).

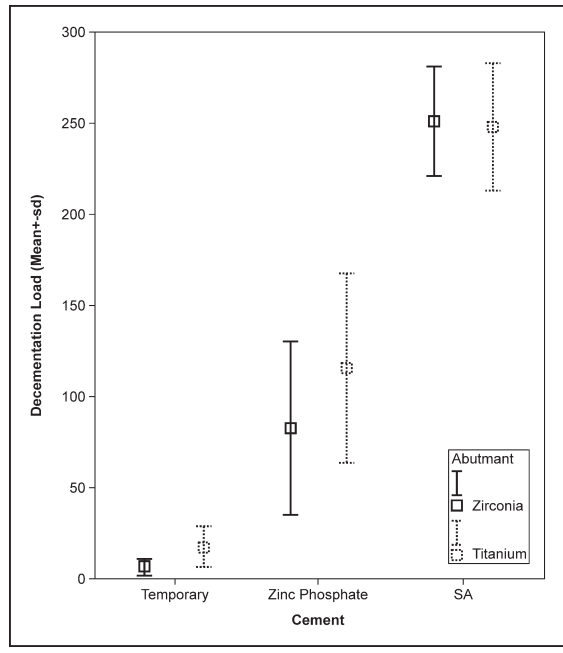

Fig. 4. Decementation load (mean and SD) for each group considering 2 factors: abutment type (zirconia; titanium) and cement type (temporary, ZOE provisional cement; zinc phosphate cement; and SA, Clearfill SA resin cement).

region, but zirconia is the most popular material for implant-retained restorations because of its strength and esthetic properties. The behaviors of the permanent and provisional luting agents used in cementation of implantsupported prostheses differ from the behavior of the agents used in cementation on natural teeth. ${ }^{23}$ In particular, water-based cements such as zinc phosphate (ZP), zinc polycarboxylate, and glass ionomer cements have shown a wide variety of retention values. ${ }^{23-25}$ Some authors have suggested that the use of permanent cements for luting single-unit restorations and provisional cements for luting multiunit implant-supported restorations ${ }^{26,27}$ because provisional cements are recommended for restorations that may require intervention, whereas more retentive cements such as resin cement are more appropriate when future retrieval is not necessary. ${ }^{28,29}$

There have been some studies on the retention of zirconia copings on titanium abutments, but there is not enough information about the retention of zirconia copings onto zirconia abutments. ${ }^{30-32}$ Therefore, the objective of this study was to evaluate the resistance to dislodgement of zirconia copings 
Table 2. Two-Way ANOVA Results for Interactions Between Abutment Types,

Cement Types, and Abutments Cements

\begin{tabular}{lcrrrr} 
& Type III Sum of Squares & $d f$ & Mean Square & \multicolumn{1}{c}{$F$} & Sig \\
\hline Abutment & 2843.622 & 1 & 2843.622 & 2.284 & 0.137 \\
Cements & 551324.369 & 2 & $275,662.185$ & 221.436 & 0.000 \\
Abutment Cements & 3251.204 & 2 & 1625.602 & 1.306 & 0.280 \\
\hline
\end{tabular}

cemented onto zirconia and titanium abutments. The null hypotheses are that neither abutment type nor cement type affect the retention of zirconia copings.

\section{Materials ANd Methods}

\section{Experimental Design}

Sixty titanium fixtures were embedded in sixty resin molds to mimic osseointegrated implants. The embedded implants were then randomly divided into 2 groups. Afterward, the specimens in group $\mathrm{A}(\mathrm{n}=30)$ were connected to titanium abutments (Straumann RC Anatomic abutment, straight titanium), and specimens in group B $(\mathrm{n}=30)$ were connected to zirconia abutments (Straumann RC anatomic IPS emax abutment, straight, Zirconium dioxide) (Fig. 1).

Sixty zirconia copings were fabricated using the $\mathrm{CAD} / \mathrm{CAM}$ process with standard external dimensions. Each coping was modified to accommodate attachment of the testing device. The copings had a 6-mm height above the abutment to provide enough space to drill a hole with diamond rotary instrument. With this hole, copings were connected by wire to the upper member of the universal testing machine.

Three types of cement were evaluated: (1) ZP cement permanent cement (Adheso; SpofaDental), (2) zinc oxide eugenol (ZOE) provisional cement (TempBond; Kerr Corporation, Orange, California), and (3) adhesive resin cement (RC) (Clearfil SA Cement; Kuraray Medical Inc, Tokyo, Japan) (Table 1). Luting cements were prepared according to the manufacturer's instructions. The copings were seated onto the abutments and loaded by compression at $20 \mathrm{~N}$ for 10 minutes (Fig. 2). Excess cement was removed from the abutment-coping junction, and the specimens were stored in distilled water at $37^{\circ} \mathrm{C}$ for 24 hours. In addition, all groups were thermocycled 5500 times between $5^{\circ} \mathrm{C}$ and $55^{\circ} \mathrm{C}$ with a dwell time of 30 seconds.

\section{Mechanical Test}

Specimens were tested under tension using a universal testing machine. The removal force was applied along the long axis of the specimens by applying a tensile force sufficient to dislodge the coping from the abutment using a tensile or pull load with a crosshead speed of 0.5 $\mathrm{mm} / \mathrm{min}$ (Fig. 3).

\section{Statistical Analysis}

The mean parameters of each group were analyzed using descriptive analysis and 2-way analysis of variance (ANOVA; Statistix 8.0 for Windows, Analytical Software Inc., Tallahassee, FL), followed by 1-way ANOVA to determine statistically significant differences among the 3 different cements. In all tests, $P$ values less than 0.05 are considered statistically significant.

\section{Table 3. One-Way ANOVA Results for 3 Kinds of Cement}

\begin{tabular}{lcrcccc} 
Abutment & Cement & Mean & SD & $P$ & Post Hoc Test (LSD) & $P$ \\
\hline Zirconia & ZOE & 6.52 & 4.67 & $<0.001$ & Temporary-ZP & $<0.001$ \\
& ZP & 83.09 & 48.3 & & Temporary-SA & $<0.001$ \\
& RC & 251.18 & 29.56 & & Zinc [phosphate-SA] & $<0.001$ \\
Titanium & ZOE & 17.82 & 10.62 & $<0.001$ & Temporary-ZP & $<0.001$ \\
& ZP & 116.41 & 51.51 & & Temporary-SA & $<0.001$ \\
& RC & 248.72 & 34.69 & & ZP-SA & $<0.001$ \\
\hline
\end{tabular}

LSD indicates least significant difference.

\section{Results}

The mean retention values and SDs are summarized in Figure 4 for titanium and zirconia abutments for the 3 kinds of cement. The $P$ values obtained in the statistical evaluation are listed in Table 2. Two-way ANOVA was performed to evaluate the differences in retention between titanium and zirconia abutments. There were no significant differences between the 2 abutment materials.

The maximum retentive force data were obtained with $\mathrm{RC}$, followed by $\mathrm{ZP}$ and then ZOE for both the titanium and zirconia abutments. The 1-way ANOVA test showed that there were significant differences among 3 cement types (Table 3 ). The mean forces necessary to remove the zirconia copings from the titanium abutments were $6.52,83.09$, and $251.18 \mathrm{~N}$ for temporary cement, ZP cement, and resin cement, respectively, and for the zirconia abutment, the required forces were $17.82,116.41$, and $248.72 \mathrm{~N}$.

\section{Discussion}

The data obtained in this study support rejecting the null hypothesis that cement type does not affect the retention of zirconia copings. However, the null hypothesis that abutment type does not affect the retention of zirconia copings is accepted. In this study, the retention was significantly influenced by the cement type. The adhesive resin showed a significantly higher retention than that of ZP and temporary cement, and no significant difference was found between the 2 abutment materials. These results are in agreement with those of Ernst et al, ${ }^{33}$ who found that composite resin cement demonstrated the highest median retentive strength. Similarly, Uo et $\mathrm{al}^{34}$ evaluated the shear bond strengths between conventional or adhesive cements and zirconia ceramic and found that phosphate-modified composite resin cements achieved significantly higher bond strengths than conventional cements.

In this study, zirconia copings were cemented onto standard zirconia and titanium abutments, and the retention values of different cements were compared after thermocycling. Because the 
aim of this study was to compare the effects of the cement type and the abutment material on retention of zirconia copings, no surface treatment was applied on the abutment materials, and the effect of the height of the abutments was not evaluated. However, there are many factors that affect the retention, as follows ${ }^{35}$ : the degree of the taper of the abutment, the height of the abutment, the roughness of abutment's surface, the surface texture (metal or ceramic), the fit of the crown on the abutment, the type of cement, the mixing ratio of the cement, the cement layer thickness, thermal cycles, and the type of dislodging force impulses.

The influence of the degree of the taper, the height of the abutment, the thermal cycles, and surface roughness has been investigated by many authors. ${ }^{36,37}$ Recently, some reports have shown that the bond strength of zirconium oxide ceramics can be improved only by airborne-particle abrasion for the ceramic surface and the use of a composite resin cement containing an adhesive phosphate monomer. ${ }^{38-41}$

Nejatidanesh et $\mathrm{al}^{42}$ evaluated the effects of different surface-treatment methods on the removal force of implant-supported zirconium oxide copings on short abutments, and they found that silicoating can improve the retentive value of zirconia copings more than $\mathrm{Al}_{2} \mathrm{O}_{3}$ airborne-particle abrasion. Abbo et a ${ }^{30}$ determined the effect of the height of a titanium abutment on the force required to dislodge a luted zirconia coping and found that a larger height of the tested abutment significantly increased the resistance to removal of the zirconia coping.

Kokubo et $\mathrm{al}^{43}$ measured and compared the retentive force of zirconia-based all-ceramic crowns cemented on zirconia abutments using 5 provisional luting agents named Hybond temporary cement hard (Hard), Hybond temporary cement soft (Soft), experimental temporary cement (New), TempBond NE (Temp), and Freegenol temporary pack (Pack). They also evaluated the effect of sandblasting and thermocycling on the retentive force. They found that Hard showed the highest retentive force and that sandblasting was effective for improving the durability of bonds formed using Hard. However, no effect of sandblasting was detected for the other luting agents. New showed a stable retentive force even after thermocycling. The retentive force of Temp and Pack decreased significantly after thermocycling even with sandblasting. Their retentive forces were different from that of the provisional cement and after sandblasting, and Temp and Pack may not be appropriate for the retention of single-tooth zirconia abutments and coping restorations. Finally, Ebert et $\mathrm{al}^{44}$ evaluated the retention of a zirconia coping bonded to a titanium abutment and concluded that the surface conditioning methods and the size of the luting gaps have a significant influence on the retention.

A perfect luting agent for implant restorations should allow dentists to vary the retentiveness of the cement depending on the clinical situation. In some situations, retrievability is indicated, whereas in other clinical situations, a permanent fixation will be the best option. Furthermore, a perfect implant luting agent should be easily and completely removable from the abutment or restoration surface.

According Nejatidanesh et al, ${ }^{25}$ the most retentive luting agent is a resinmodified glass ionomer cement, but they found no significant difference between the resin-modified glass ionomer cement and Panavia 2.0, ZP, and zinc polycarboxylate cements. These definitive cements are recommended for luting single-unit implant-supported metal restorations. The temporary and glass ionomer cements were the least retentive cements and might not be suitable for luting single-unit implantsupported restorations. ${ }^{25}$

Singer et $\mathrm{al}^{45}$ reported clinical success using provisional luting agents for implant restorations. These restorations were superior to screw-retained implant prostheses, but cement washouts were observed in all cases within the first year of service in the posterior region.

To understand the retention of the zirconia copings cemented onto zirconia and titanium abutments, different surface-treatment protocols, different heights and degrees of taper of the abutment, different aging procedures, and different cement layer thickness should also be evaluated in the future.

\section{Conclusions}

1. The choice of zirconia or titanium abutment material has no effect on retention.

2. The cement type affects the retention of the zirconia copings. Resin cement has a higher retention value than temporary cement and $\mathrm{ZP}$ cement on both titanium and zirconia abutments.

\section{Clinical Implications}

The results in this study will inform the appropriate choice of cement for zirconia restorations on zirconia or titanium abutments. The adhesive resin showed a significantly higher retention than ZP and temporary cement, which makes it more appropriate for permanent restorations.

\section{Disclosure}

The authors claim to have no financial interest, either directly or indirectly, in the products or information listed in the article.

\section{ACKNOWLEDGMENTS}

This article is dedicated to the first author, Dr. U. Güler, who recently died unexpectedly.

\section{REFERENCES}

1. Nakamura K, Kanno T, Milleding $P$, et al. Zirconia as a dental implant abutment material: A systematic review. Int $J$ Prosthodont. 2010;23:299-309.

2. Schiroli G. Single-tooth implant restorations in the esthetic zone with PureForm ceramic crowns: 3 case reports. J Oral Implantol. 2004;30:358-363.

3. Ormianer Z, Schiroli G. Maxillary single-tooth replacement utilizing a novel ceramic restorative system: Results to 30 months. J Oral Implantol. 2006;32: 190-199.

4. Apicella D, Veltri M, Chieffi $N$, et al. Cement thickness at implant-supported single-tooth lava assemblies: A scanning electron microscopic investigation. Clin Oral Implants Res. 2010;21:747-750. 
5. Yildirim M, Fischer H, Marx R, et al. In vivo fracture resistance of implant-supported all-ceramic restorations. J Prosthet Dent. 2003;90:325-331.

6. Aramouni P, Vigolo P, Majzoub Z, et al. Evaluation of rotational freedom of In-Ceram ceramic blank abutments before and after infiltration. Implant Dent. 2010; 19:50-56.

7. Denry I, Kelly JR. State of the art of zirconia for dental applications. Dent Mater. 2008;24:299-307.

8. Ortorp A, Kihl ML, Carlsson GE. A 3-year retrospective and clinical follow-up study of zirconia single crowns performed in a private practice. J Dent. 2009;37:731736.

9. Jung RE, Pjetursson BE, Glauser R, et al. A systematic review of the 5-year survival and complication rates of implant-supported single crowns. Clin Oral Implants Res. 2008;19:119-130.

10. Scarano A, Piattelli M, Caputi S, et al. Bacterial adhesion on commercially pure titanium and zirconium oxide disks: An in vivo human study. J Periodontol. 2004;75:292-296.

11. Uo M, Sjögren G, Sundh A, et al. Cytotoxicity and bonding property of dental ceramics. Dent Mater. 2003;19: 487-492.

12. Abrahamsson I, Berglundh $\mathrm{T}$, Glantz PO, et al. The mucosal attachment at different abutments. An experimental study in dogs. J Clin Periodontol. 1998;25:721-727.

13. Zembic A, Sailer I, Jung RE, et al. Randomized-controlled clinical trial of customized zirconia and titanium implant abutments for single-tooth implants in canine and posterior regions: 3-year results. Clin Oral Implants Res. 2009;20:802-808.

14. Piconi C, Maccauro G. Zirconia as a ceramic biomaterial. Biomaterials. 1999; 20:1-25.

15. Hisbergues M, Vendeville $S$, Vendeville P. Zirconia: Established facts and perspectives for a biomaterial in dental implantology. J Biomed Mater Res B Appl Biomater. 2009;88:519-529.

16. Aboushelib MN, Salameh Z. Zirconia implant abutment fracture: Clinical case reports and precautions for use. Int J Prosthodont. 2009;22:616-619.

17. Alqahtani F, Flinton R. Post-fatigue fracture resistance of modified prefabricated zirconia implant abutments. J Prosthet Dent. 2014;112:299-305.

18. Sailer I, Philipp A, Zembic A, et al. A systematic review of the performance of ceramic and metal implant abutments supporting fixed implant reconstructions. Clin Oral Implants Res. 2009;20(suppl 4): 4-31.

19. Butz F, Heydecke G, Okutan M, et al. Survival rate, fracture strength and failure mode of ceramic implant abutments after chewing simulation. J Oral Rehabil. 2005;32:838-843.

20. Att W, Kurun S, Gerds T, et al. Fracture resistance of single-tooth implant-supported all-ceramic restorations: An in vitro study. J Prosthet Dent. 2006;95:111-116.

21. Gehrke P, Dhom G, Brunner J, et al. Zirconium implant abutments: Fracture strength and influence of cyclic loading on retaining-screw loosening. Quintessence Int. 2006;37:19-26.

22. Aramouni P, Zebouni E, Tashkandi $E$, et al. Fracture resistance and failure location of zirconium and metallic implant abutments. J Contemp Dent Pract. 2008; 9:41-48.

23. Wolfart M, Wolfart S, Kern M. Retention forces and seating discrepancies of implant-retained castings after cementation. Int J Oral Maxillofac Implants. 2006;21:519-525.

24. Montenegro AC, Machado AN, Depes Gouvea CV. Tensile strength of cementing agents on the CeraOne system of dental prosthesis on implants. Implant Dent. 2008;17:451-460.

25. Nejatidanesh F, Savabi O, Ebrahimi $M$, et al. Retentiveness of implantsupported metal copings using different luting agents. Dent Res J (Isfahan). 2012; 9:13-18.

26. Akca K, Iplikcioglu H, Cehreli MC. Comparison of uniaxial resistance forces of cements used with implant-supported crowns. Int J Oral Maxillofac Implants. 2002; 17:536-542.

27. Hill EE. Dental cements for definitive luting: A review and practical clinical considerations. Dent Clin North Am. 2007;51:643-658, vi.

28. Ramp MH, Dixon DL, Ramp LC, et al. Tensile bond strengths of provisional luting agents used with an implant system. J Prosthet Dent. 1999; 81:510-514.

29. Dudley JE, Richards LC, Abbott JR. Retention of cast crown copings cemented to implant abutments. Aust Dent J. 2008;53:332-339.

30. Abbo B, Razzoog ME, Vivas J, et al. Resistance to dislodgement of zirconia copings cemented onto titanium abutments of different heights. J Prosthet Dent. 2008;99:25-29.

31. Sundh A, Molin M, Sjogren G. Fracture resistance of yttrium oxide partially-stabilized zirconia all-ceramic bridges after veneering and mechanical fatigue testing. Dent Mater. 2005;21: 476-482.

32. Lüthy $H$, Filser $F$, Loeffel $O$, et al. Strength and reliability of four-unit allceramic posterior bridges. Dent Mater. 2005;21:930-937.
33. Ernst CP, Cohnen U, Stender E, et al. In vitro retentive strength of zirconium oxide ceramic crowns using different luting agents. J Prosthet Dent. 2005;93:551-558.

34. Uo M, Sjögren G, Sundh A, et al. Effect of surface condition of dental zirconia ceramic (Denzir) on bonding. Dent Mater J. 2006:25:626-631.

35. Schiessl C, Schaefer L, Winter C, et al. Factors determining the retentiveness of luting agents used with metal- and ceramic-based implant components. Clin Oral Investig. 2013;17: 1179-1190.

36. Bernal G, Okamura M, Munoz CA. The effects of abutment taper, length and cement type on resistance to dislodgement of cement-retained, implant-supported restorations. J Prosthodont. 2003;12:111115.

37. Covey DA, Kent DK, St Germain HA Jr, et al. Effects of abutment size and luting cement type on the uniaxial retention force of implant-supported crowns. J Prosthet Dent. 2000;83:344348.

38. Kern M, Wegner SM. Bonding to zirconia ceramic: Adhesion methods and their durability. Dent Mater. 1998;14:6471.

39. Wegner SM, Gerdes W, Kern M. Effect of different artificial aging conditions on ceramic-composite bond strength. Int J Prosthodont. 2002;15: 267-272.

40. Lüthy $\mathrm{H}$, Loeffel $\mathrm{O}$, Hammerle $\mathrm{CH}$. Effect of thermocycling on bond strength of luting cements to zirconia ceramic. Dent Mater. 2006;22:195-200.

41. Wolfart M, Lehmann F, Wolfart S, et al. Durability of the resin bond strength to zirconia ceramic after using different surface conditioning methods. Dent Mater. 2007;23:45-50.

42. Nejatidanesh F, Savabi O, Jabbari E. Effect of surface treatment on the retention of implant-supported zirconia restorations over short abutments. J Prosthet Dent. 2014:112: 38-44

43. Kokubo $Y$, Kano $T$, Tsumita $M$, et al. Retention of zirconia copings on zirconia implant abutments cemented with provisional luting agents. J Oral Rehabil. 2010;37:48-53.

44. Ebert A, Hedderich J, Kern M. Retention of zirconia ceramic copings bonded to titanium abutments. Int $J$ Oral Maxillofac Implants. 2007;22:921927.

45. Singer A, Serfaty V. Cementretained implant-supported fixed partial dentures: A 6-month to 3-year follow-up. Int J Oral Maxillofac Implants. 1996;11: 645-649. 